\title{
Clinical Observations Location
}

National Cancer Institute

\section{Source}

National Cancer Institute. Clinical Observations Location. NCI Thesaurus. Code C119804.

The site in or on the body at which the clinical observation is made. 